Chapter 7

\title{
Soil Behaviour Characteristics Under Applied Forces in Confined and Unconfined Spaces
}

\author{
Seth I. Manuwa \\ Additional information is available at the end of the chapter \\ http://dx.doi.org/10.5772/52774
}

\section{Introduction}

Soil strength has been regarded as important characteristics that affect many aspects of agricultural soils, such as the performance of cultivation implements, root growth, leastlimiting water range and trafficabilty [1]. They further reported that characterization of soil strength is usually made by measuring the response of a soil to a range of applied forces.

Soil compaction may be defined as the densification of unsaturated soil due to reduction in air volume without change in mass wetness [2].Soil compaction occurs in unsaturated soils when subjected to mechanical forces [3]. While soil compaction is essential in many engineering works (especially civil engineering) it is undesirable in agricultural production to a large extent. Compaction reduces the soil permeability to water, so that run off and erosion may occur and adequate recharge of ground water is prevented. Compaction reduces regeneration of the soil, so that metabolic activities of roots are impaired. Compaction increases the mechanical strength of the soil, so root growth is impeded. It is known that in agricultural system, the risk of soil compaction increases with the growth of farm size, increased mechanization and equipment weight, and the drive for greater productivity. Soil compaction also has negative effects on the environment by increasing runoff and erosion thereby accelerating potential pollution of surface water by organic wastes and applied agrochemicals [4]. All of these effects may reduce the quality and quantity of food and fibre grown on the soil. Therefore, the knowledge of soil compaction is increasingly important and desirable within agriculture and environmental protection.

The state of soil compactness is expressed in several ways: bulk density (expressed on a wet or dry basis), porosity and apparent specific gravity [5]. Accurate compaction behaviour equations will provide a means to predict compaction. The ability to predict compaction is the first requirement for attaining control of compaction. Considerable research has been per- 
formed in attempts to develop soil compaction behaviour equations [6, 7, 8, 9, 10, 11, and 12]. Others have also reported on effects of organic matter and tractor passes on compaction and yield of crops $[13,14]$.

The aim of this chapter therefore was to observe the behaviour of textured soils under uniaxial compression in confined spaces and also in unconfined spaces under the influence of agricultural machines as it is affected by applied pressure and water content and also to model the behaviour using regression analysis for the purpose of prediction.

\section{Soil under pressure}

When forces are applied to soil it changes its stateof compactness to have greater density. The pressure can be applied pressure or natural forces. Applies pressure can be due to animals like horses and cattle $(160 \mathrm{kPa})$, man $(95 \mathrm{kPa})$, sheep $(60 \mathrm{kPa})$. The pneumatic wheels of vehicles can be inflated to $100 \mathrm{kPa}$ for tractors and $200 \mathrm{kPa}$ for for trailers and may produce local stresses twice these values [3]. The problem therefore is that over the years arable soils have suffered degradation as a result of excessive compaction of surface and sub surface soil horizon through overuse of agricultural machinery. This trend has global phenomenon as man labours to meet the ever increasing demand for food, feed and fibre for the increasing population of the world.

\subsection{Application area}

Soil compaction has many areas of application in human endeavour apart from agriculture and forestry. When a seed is sowed the soil has to be sufficiently firmed around it (compacted) to to enable it germinate. Arable terrains require appropriate level of compaction for it to be effectively trafficked by running gears like wheels and tracks. In sports the field must have the required strength or bearing capacity (a measure of some level of compaction) for it to be good for sporting activities.

\subsection{Research course}

In this chapter soil compaction is considered in two regimes: in confined and unconfined spaces. The former is typical of studies under laboratory conditions while the latter signifies field conditions. The three experimental soils studied under uni-axial compression have textures of sandy clay loam, loamy sand and silt loam according to the USDA Soil Textural Classification, while the soil studied under field condition was sandy clay. In Nigeria, published data on compressibility and compaction of agricultural and forestry soils are scarce. The development and implementation of practical guidelines in order to manage soil compaction for a wide range of machinery types and forestry soils depend upon an understanding of the relative importance of applied pressure and water content during the compaction process. 


\section{Materials and method}

\subsection{Sites of samples}

i. Confined compression test: soil samples were taken from three sites for the confined compression tests.

a. Akure sandy clay loam soil: the site was a portion of agricultural land under fallow at the Federal University of Technology, Akure, Nigeria $\left(7^{0} 15^{1} \mathrm{~N}, 5^{0} 15^{1} \mathrm{E}\right)$, and elevation $210 \mathrm{~m}$. The soil is Oxic paleustalf (Alfisol) or ferric Luvisol (FAO). A mini soil pit was dug to expose the profile. The site was designated Experimental Bin Soil (EBS). Three horizons EBS1, EBS2, and EBS3, from top to bottom respectively, were identified and samples taken from each. The thickness of the three horizons from top to bottom was 8,15 and $15 \mathrm{~cm}$, respectively.

b. Igbokoda loamy sand soil: the soil used in this study was the major soil predominant in Igbokoda (headquarters of Ilaje Local Government area), Ondo State, South Western Nigeria. The soils were collected from the main agricultural production areas. This region is predominantly rainforest zone. Rainfall is in the order of $150 \mathrm{~cm}$ to $300 \mathrm{~cm}$ per annum, and mean annual temperature ranges from 25 to $28^{\circ} \mathrm{C}$. Soil samples were taken from freshly cut faces in open shallow pit to dept of $40 \mathrm{~cm}$.

c. Ilorin silt loam soil: the soil sample was taken from the arable soils of National Centre for Agricultural Mechanization (NCAM) Ilorin, Kwara State, Nigeria (8.30 N 4.32 E). The soil was Regosols (FAO). The soil samples were collected from the first $35 \mathrm{~cm}$ of soil profile; each sample was dug to a radius of $15 \mathrm{~cm}$ and then mixed thoroughly to get a homogeneous mixture, and then taken to the laboratory for further processing and analysis.

\section{ii. Unconfined Compression Test}

The study was carried out in August 2010 in an experimental plot located at The Federal University of Technology, Akure (FUTA) Step-B (Science and Technology Education Post Basic) project site Akure, with geographical coordinate of $7^{\circ} 10$ North and $5^{\circ} 05$ East. The site is a two-hectare arable land and was manually cleared to avoid compaction due to machinery impacts on the land. The experimental plot of length and width $48.00 \mathrm{~m}$ by $12.00 \mathrm{~m}$, respectively, was divided into three transects each of $16 \mathrm{~m}$ by $4 \mathrm{~m}$. There was also a control plot of the same dimensions as transect. Soil samples were carefully collected from the test plots for textural and soil analysis.

\subsection{Analytical methods}

Particle size analyses of all the experimental soils for both confined and unconfined samples were performed using hydrometer method [16]. Organic matter content of the soils was determined using the [16] method. Other physical and chemical properties of the soils were also determined using standard methods. 


\subsection{Confined compression tests}

i. Akure sandy clay loam soil: sample were collected, air-dried and ground to pass through a 2- $\mathrm{mm}$ sieve. The moisture content level for compaction for each soil sample was chosen according to the consistency limits of the soils determined by the procedure described [15]. Soil sample was placed in aluminium sleeve $75 \mathrm{~mm}$ in diameter and $50 \mathrm{~mm}$ long similar to that described 11].The cylinder was then placed on a $5 \mathrm{~mm}$ perforated metal base before the soil was added and tapped gently tapped to allow settling of the soil particles. Such prepared soil samples in the cylinders were then subjected to applied pressures 17.5, 100, 200, 300, 400, 500 and $618 \mathrm{kPa}$ in turn applied by an Hydraulic Universal Testing machine (SM100, model No CPI-60) of 0.1 kN sensitivity, manufactured by TEC QUIPMENT Ltd, Nottingham, England). A hand pump of the machine was used to generate the required pressure on the soil. The soil samples were allowed to rebound before final heights were measured. The depression in the soil surface from the rim of the cylinder was measured at three points around the core by using a vernier caliper. These measurements were used to calculate bulk density in each test.

ii. Igbokoda Loamy Sand Soil: similarly, samples were air-dried and pulverized to pass through a $2 \mathrm{~mm}$ sieve. Each soil was wetted to a range of water contents between saturation and wilting point. For each sample, approximately $2 \mathrm{~kg}$ or air-dry soil was poured into a plastic tray. The soil was wetted with an atomizer and thoroughly mixed to bring the soil to the desired water content. The tray was then placed in a plastic bag and the sample was allowed to equilibrate for $48 \mathrm{hr}$. After equilibration, a soil sample at particular water content was placed in steel sleeve, $90 \mathrm{~mm}$ in diameter and $100 \mathrm{~mm}$ long. The cylinders were then placed on a $5 \mathrm{~mm}$ perforated metal base with cheesecloth before the soil was added. The cylinders were gently tapped to allow settling of the soil particles. Soil samples in the cylinders were then subjected to applied pressures of $0,17.5,100,175,289.5,404,511$ and $618 \mathrm{kPa}$ respectively, applied by a Universal Testing machine (SM100, model No CPI-60) of $0.1 \mathrm{kN}$ sensitivity, manufactured by TEC QUIPMENT Ltd, Nottingham, England), consisting of an hydraulic ram connected to a piston. The compression force was read through a digital load meter. A hand pump was used to generate the required pressure on the soil. The pressure was maintained for a few second and then released. The samples were allowed to 'rebound' before final heights were measured. Water and air could escape around the piston and through fine perforations in the base plate. The depression in the soil surface from the rim of the cylinder was measured at three points around the core by using a vernier scale. This procedure was similar to that reported by research ${ }^{[10]}$. These measurements were used later to calculate bulk density.

iii. Ilorin Silt Loam Soil: samples were collected were each air-dried and ground to pass through a 2-mm sieve. The moisture levels for compaction tests were chosen according to the consistency limits of the soils determined by the procedure described by [15]. Compaction test was performed by filling the proctor mould with a known mass of soil and placed under a uni-axial compression apparatus (Universal Testing Machine (UTM), manufactured by the Testometric Co. Ltd., U. K.). Compression was carried out at a steady speed of $30 \mathrm{~mm} / \mathrm{min}$. Soil samples in the mould were subjected 
in turn to $75,100,150,200,300,400,500,600 \mathrm{kPa}$. The soil displacement and mass were recorded for each compaction treatment. The mass was used to calculate bulk density of the compacted soil sample. The proctor mould was $16.8 \mathrm{~cm}$ height and 10 $\mathrm{cm}$ diameter. A circular thick metal plate was placed on the compression end of the UTM to effect uniform compaction in the proctor mould. After each compaction test, the change in depth of compressed soil was measured with the aid of a digimatic vernier caliper.

\subsection{Penetration resistance measurement}

Penetration resistance or Cone index (CI) was determined using a Rimick CP20 recording penetrometer (model CP 20 ultrasonic, Agridry Rimik Pty Ltd, Toowoomba), with a standard $30^{\circ}$ cone of $322-\mathrm{mm}^{2}$ base area and a penetration rate was less than $10 \mathrm{~mm} / \mathrm{s}$. Measurements were taken at two depths 5 and $10 \mathrm{~cm}$ of the proctor mould and the average of the readings was taken as the representative value of cone index at that test.

\subsection{Shear strength measurement}

Shear strength values of experimental soils were observed using a shear vane tester of $19 \mathrm{~mm}$ vane. Measurements were taken at two depths of 5 and $10 \mathrm{~cm}$ in the Proctor's mould and the average recorded to represent the shear strength of the specific sample treatment.

\subsection{Unconfined compression test}

i. Experimental treatments and layout: the machinery used for this specific study was a medium Bobcat 430 Excavator of $31.9 \mathrm{~kW}$ power used to induce the necessary compaction on the experimental plots. The characteristics of the excavator are presented in Table 1. Seven treatments were imposed on plots $48 \mathrm{~m}$ long $\times 4 \mathrm{~m}$ wide, while the experimental variable was traffic frequency of $0,1,3,5,7,9$ and 11 excavator passes on the same tracks, with $3 \mathrm{~m}$ wide buffer zones between plots to avoid interactions. Plots were completely randomized having three replications. Statistical analysis was performed utilizing Excel 2007. An analysis of variance was carried out on the data and means were analyzed by Duncan's multiple range test.

ii. Soil response variables: experimental variables related to soil compaction include dry bulk density measured by the cylinder core soil sampler method, soil moisture content measured with moisture meter model PMS- 714, Taiwan with $0.1 \%$ resolution over the depth ranges of 0-10, 10-20, 20-30, 30-40 mm. Bulk density was the average of five measurements. Moisture content was verified by gravimetric method. Soil penetration resistance PR, or cone index CI was determined using a Rimick CP20 recording penetrometer (model CP 20 ultrasonic, Agridry Rimik Pty Ltd, Toowoom$\mathrm{ba}$ ), with a standard $30^{\circ}$ cone of $322-\mathrm{mm}^{2}$ base area. The penetration rate was less than $10 \mathrm{~mm} / \mathrm{s}$. Data were recorded at depth increments of $50 \mathrm{~mm}$. Cone index was the average of 15 measurements per plot. The resistance of the soil was measured in the centre line of the foot print of the excavator tract. Rut depth of the excavator foot print was measured using a profile meter similar to that reported [18]. The bar was placed across the wheel tracks, perpendicular to the direction of travel and rods position to 
conform to the shape of the depression. Rut depth was calculated as the average depth of 40 readings on the 1 metre bar. The estimated rut depth at any traffic frequency was calculated as the mean of the total number of sections' ruts at that frequency.

\section{Results and discussion}

\subsection{Confined compression}

\subsubsection{Sandy clay loam soil}

The physical and some other properties of the experimental sandy clay loam soil are shown in Table 2.Soil samples EBS1 and EBS2 have similar characteristics yet not the same as they are different physically especially in colour which may be due to presence of more dead organic material in the EBS1 than in the EBS2. Bulk density increased with increase in applied pressure, initially at a decreasing rate and further reaching an asymptotic value especially at applied pressure of about $600 \mathrm{kPa}$ and beyond. Most relationships observed between soil bulk density and applied pressures were nonlinear. At moisture contents less than $12.9 \%$, it was observed that bulk density change little with applied pressure in the soil as reflected from the third horizon. There was little change in bulk density between 0 and $600 \mathrm{kPa}$ pressure. This can be adduced to relatively high clay content of the third horizon (EBS3), and its least organic carbon content. A clay soil is naturally more compact than a sandier or silty soil; hence its bulk density changes little under applied pressure. Generally, a very strong correlation was observed for relationship between applied pressure and bulk density, $R^{2}$ values ranged from 0.92 to 0.99 . The relationships between applied pressures for horizon 1 are represented by equations (1) to (5) for moisture contents of $10.4,8.4,4.7,3.5$ and $1.6 \%$, respectively.

\begin{tabular}{|c|c|c|c|c|c|c|c|c|}
\hline \multirow[t]{2}{*}{ Soil Type } & \multicolumn{3}{|c|}{$\begin{array}{c}\text { Texture } \\
\text { Sand silt clay }\end{array}$} & \multirow{2}{*}{$\begin{array}{c}\text { Bulk density } \\
\mathrm{Mg} / \mathrm{m}^{3}\end{array}$} & \multirow{2}{*}{$\begin{array}{l}\text { Sat hyd cond } \\
\mathrm{mm} / \mathrm{min}\end{array}$} & \multirow[t]{2}{*}{ Clay ratio } & \multirow[t]{2}{*}{ Clay + silt } & \multirow{2}{*}{$\begin{array}{c}0 . C \\
\%\end{array}$} \\
\hline & $\%$ & $\%$ & $\%$ & & & & & \\
\hline $\begin{array}{l}\text { Sandy clay loam } \\
\text { (EBS1) }\end{array}$ & 54 & 21 & 25 & 1.43 & 1.21 & 33.3 & 46 & 1.41 \\
\hline $\begin{array}{l}\text { Sandy clay loam } \\
\text { (EBS2) }\end{array}$ & 54 & 21 & 25 & 1.55 & 1.22 & 33.3 & 46 & 1.22 \\
\hline $\begin{array}{l}\text { Sandy clay loam } \\
\text { (EBS3) }\end{array}$ & 52 & 17 & 31 & 1.39 & 0.85 & 44.9 & 48 & 0.87 \\
\hline
\end{tabular}

Table 2. Physical Properties of experimental sandy clay loam Soils

$$
\mathrm{BD}=0.8654 \mathrm{X}^{0.114}\left(\mathrm{R}^{2}=0.9967\right)
$$




$$
\begin{gathered}
\mathrm{BD}=0.09763 \mathrm{X}^{0.083}\left(\mathrm{R}^{2}=0.9805\right) \\
\mathrm{BD}=0.079 \operatorname{Ln}(\mathrm{X})+1.089\left(\mathrm{R}^{2}=0.9938\right) \\
\mathrm{BD}=0.0005 \mathrm{X}+1.189\left(\mathrm{R}^{2}=0.9312\right) \\
\mathrm{BD}=1.342 \mathrm{e} 0.0002 X\left(\mathrm{R}^{2}=0.9899\right)
\end{gathered}
$$

where $\mathrm{BD}=$ bulk density, $\mathrm{Mg} / \mathrm{m}^{3}$ and

$\mathrm{X}=$ applied pressure, $\mathrm{kPa}$

Similarly, the relationships between applied pressure and bulk density for horizon 2 (EBS2) are represented by equations (6) to (11) below representing those for moisture contents of 17.0, $10.2,7.4,5.1,3.6$, and $2.2 \%$, respectively.

$$
\begin{gathered}
\mathrm{BD}=0.187 \operatorname{Ln}(X)+0.907 \quad\left(R^{2}=0.9562\right) \\
\mathrm{BD}=0.163 \operatorname{Ln}(X)+0.736 \quad\left(R^{2}=0.9968\right) \\
\mathrm{BD}=1.115 \mathrm{X}^{0.066} \quad\left(\mathrm{R}^{2}=0.9826\right) \\
\mathrm{BD}=0.091 \operatorname{Ln}(X)+1.065\left(\mathrm{R}^{2}=0.9842\right) \\
\mathrm{BD}=1.267 \mathrm{X}^{0.042} \quad\left(\mathrm{R}^{2}=0.9455\right) \\
\mathrm{BD}=1.403 \mathrm{e}^{0.0001 X} \quad\left(\mathrm{R}^{2}=0.9539\right)
\end{gathered}
$$

$\mathrm{X}=$ applied pressure, $\mathrm{kPa}$

Furthermore, the relationships between applied pressure and bulk density for horizon 3 (EBS3) are represented by equations (12) to (16) below representing those for moisture contents of $12.95,7.7,6.4,5.5$ and $2.3 \%$, respectively. 


$$
\begin{gathered}
\mathrm{BD}=0.225 \operatorname{Ln}(\mathrm{X})+0.604\left(\mathrm{R}^{2}=0.9787\right) \\
\mathrm{BD}=1.006 \mathrm{X}^{0.079} \quad\left(\mathrm{R}^{2}=0.9859\right) \\
\mathrm{BD}=1.222 \mathrm{X}^{0.051}\left(\mathrm{R}^{2}=0.9287\right) \\
\mathrm{BD}=1.416 \mathrm{X}^{0.019} \quad\left(\mathrm{R}^{2}=0.9028\right) \\
\mathrm{BD}=1.425 \mathrm{X}^{0.015} \quad\left(\mathrm{R}^{2}=0.9954\right)
\end{gathered}
$$

where $\mathrm{BD}=$ bulk density, $\mathrm{Mg} / \mathrm{m}^{3}$ and

$\mathrm{X}=$ applied pressure, $\mathrm{kPa}$

The above models (equations 1 to 16) were best fitted equations to the experimental values of the bulk density-applied pressure relationships. They enable prediction of bulk density of the soil to be possible in the range of moisture content and applied pressure considered in this study. The study showed that four types of models (power, logarithmic, exponential and linear functions) could be used to describe the relationship of bulk density and applied pressure at a specific moisture level, judging from their high coefficients of determination that ranged from 0.9028 to 0.9968 . However, the best model at each moisture content level was reported in this paper. Power function seemed to be the best and most popular model, followed by logarithmic, exponential and linear function in that order. Substituting extra values of applied pressure and moisture content, which were not used in establishing the models, validated the models. There was high correlation $(\mathrm{r}>0.9936)$ between predicted and measured values of bulk density and the errors less than $5.6 \%$. Other researchers had reported similar result. Researchers [20] fitted exponential curves for loamy soils while [21] reported logarithmic curves. Researchers [3] fitted logarithmic and power functions for sandy loam and clay soils at different moisture content levels and applied pressure. Figures 1, 2 and 3 indicate that irrespective of soil horizon of the soil sample and applied pressure, soil compactability increased as the moisture content increased to a limit. Generally, bulk density increased with moisture content irrespective of the value of applied pressure. Compaction caused squeezing out of water from the pores, especially the macrospores. The implication is that tillage whether manual or mechanical should be done when the soil is moist rather than wet condition. From this work, moisture content of $10 \%$ and above is unfavourable since soil compaction at these levels of moisture content would enhance soil compaction as indicated by excessively high soil bulk density. Considering the bulk density value of $1.5 \mathrm{Mg} / \mathrm{m}^{3}$ which is indicated to be critical for crop production [22], the moisture contents of 10.0 (Figure 1), 17.0 (Figure 2) and 12.9\% (Figure 3) are liable to produce high bulk density if pressure is applied at $200 \mathrm{kPa}$ and above. The recommended moisture content for minimizing soil compaction (for sandy clay loam) or 
soil bulk density is less than $10 \%$ and the applied pressure should not exceed $200 \mathrm{kPa}$, as indicated by this study.

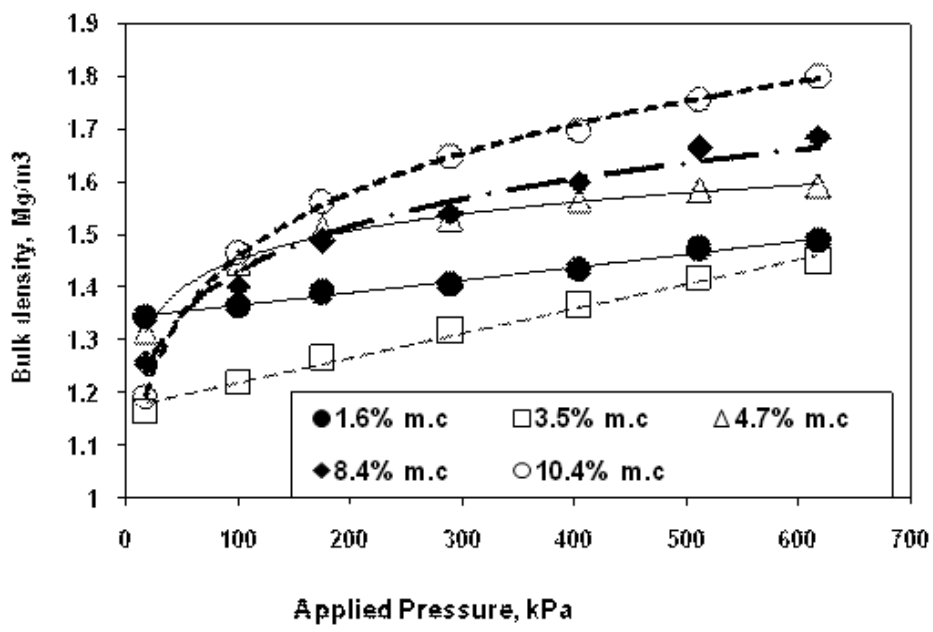

Figure 1. Effect of applied pressure, moisture content on bulk density of sandy clay loam soil (EBS1), Layer1 $(54,21,25)$

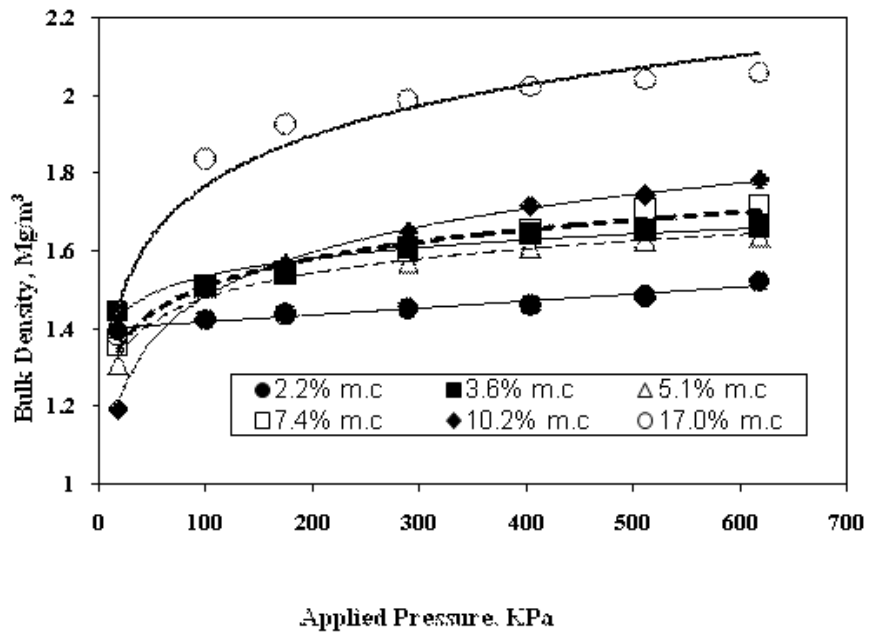

Figure 2. Effect of applied pressure, moisture content on bulk density of sandy clay loam soil (EBS2), Layer2 $(54,21,25)$ 
The compatibility of the soils was also considered in terms of the minimum increase in compaction (when the soil was dry) and maximum increase in compaction (when the soil was wet). For the soil in the uppermost horizon (EBS1), the minimum and maximum increases in compaction were 5.5 and $61.5 \%$ respectively. For the soil in the middle horizon (EBS2), the values were 3.9 and $53.6 \%$ while for the bottom horizon; the values are 4.5 and $76.9 \%$ respectively. From the foregoing, it was obvious that sandy clay loam soils are sensitive to water content at the time of compaction. This is in agreement with the findings reported by [11]. The results also show that the percentage increase in soil compaction for the sandy clay loan is related more to changes in water content than to applied pressure. Scheduling tillage operations on this type of soil in drier condition will have greatest benefit in lowering soil compaction not withstanding changes in ground pressure.

\subsubsection{Loamy sand soil}

Physical and some other properties of the loamy sand soil are shown in Table3. Values of bulk density (ordinate) were plotted against applied pressure (abscissa). The best-fit models at each moisture level were established using regression analysis with the regression models and their coefficients shown (Table 4). The models vary from linear to intrinsically linear models: Linear fit (LINFIT); Exponential fit (EXPFIT); Logarithmic fit (LOGFIT) and power fit (PWRFIT). It was observed that experimental soil showed similar behaviour under compression when it is very dry and when it is almost saturation. This report is similar to that reported elsewhere ${ }^{[10]}$. The linear model describing the compression at those moisture levels could explain this. At intermediate moisture contents, the models are only intrinsically linear. The high coefficients of correlation of the models showed that the models are adequate for the prediction of the soil behaviour. It was reported [11] that the values for applied pressure should be regarded as relative and that the pressure required in a uni-axial test to produce the same bulk density in the field was considerably higher [23].

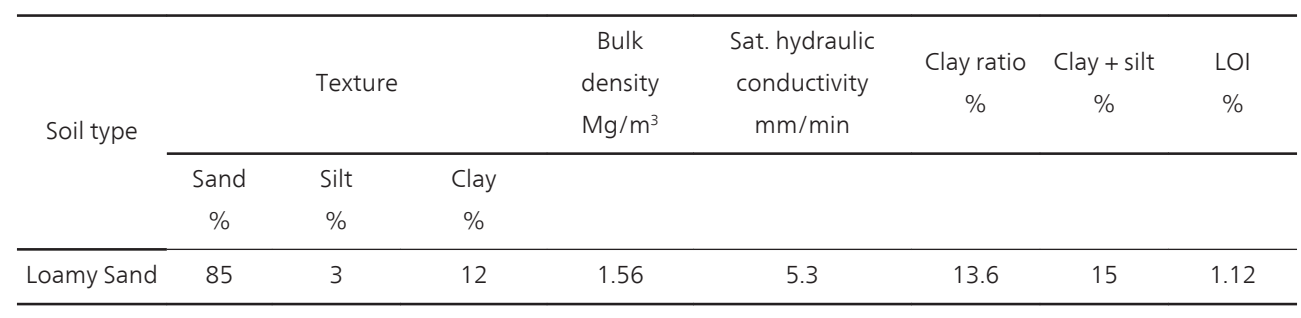

Table 3. Physical properties of the experim ental loamy sand soil

Effect of moisture content on bulk density: The variation of bulk density with water content at the different levels of applied pressure is governed by a quadratic relationship of the type shown in Equation (17). It is observed that bulk density decreased with increase in water content at any particular applied pressure, to a minimum density and then increased again. The range of applied pressure considered (17.5 to $618 \mathrm{kPa}$ ) covered the range common in agricultural productions. For the purpose of predictions, best models were established to fit 
the data of bulk density variation with moisture content. By simply "eyeballing" the data in the scatter diagram, it was apparent that a parabolic (or quadratic model) was the best model. This was confirmed by comparing the coefficients of determination of possible models:

$$
y=A+B x+C x^{2}
$$

where $y=$ bulk density $\left(\mathrm{Mg} / \mathrm{m}^{3}\right), x=$ moisture content, $\%(\mathrm{db}), \mathrm{A}, \mathrm{B}, \mathrm{C}=$ regression coefficients, $\mathrm{R}^{2}=$ coefficient of determination. The coefficients of the model are presented in Table 5. The values of the $\mathrm{R}^{2}$ were high enough to make the models suitable for predictions.

\begin{tabular}{|c|c|c|c|}
\hline MC (\%) db & Model type & Correlation coeff. (r) & Model Equation \\
\hline 0.01 & (LINFIT) & 0.9956 & $\rho_{b}=1.5913+7.898 E-5 \sigma$ \\
\hline 0.1 & (EXPFIT) & 0.9908 & $\rho_{b}=1.4405 \operatorname{EXP}(1.043 E-4 \sigma)$ \\
\hline 1.6 & (LINFIT) & 0.9830 & $\rho_{b}=1.3697+1.411 E-4 \sigma$ \\
\hline 1.9 & (LOGFIT) & 0.9943 & $\rho_{b}=1.09158+5.413 E-21 n \sigma$ \\
\hline 4.5 & (PWRFIT) & 0.9977 & $\rho_{\mathrm{b}}=1.127 \sigma^{0.0397}$ \\
\hline 4.7 & (PWRFIT) & 0.9900 & $\rho_{b}=1.216 \sigma^{0.0327}$ \\
\hline 8.0 & (LOGFIT) & 0.9938 & $\rho_{b}=1.0416+0.071 \mathrm{n} \sigma$ \\
\hline 10.4 & (PWRFIT) & 0.9828 & $\rho_{b}=1.3086 \sigma^{0.0252}$ \\
\hline 13.0 & (LINFIT) & 0.9919 & $\rho_{b}=1.4728+0.000213 \sigma$ \\
\hline
\end{tabular}

LINFIT = Linear fit $;$ EXPFIT = Exponential fit LOGFIT = Logarithmic fit; PWRFIT = Power fit

Table 4. Bulk density and applied pressure relationships at different moisture content for Igbokoda loamy sand soil.

\begin{tabular}{lllll}
\hline & \multicolumn{4}{c}{ Model Coefficients } \\
\cline { 2 - 5 } & Pressure $(\mathrm{kPa})$ & $\mathrm{B}$ & $\mathrm{C}$ & $\mathrm{R}^{2}$ \\
\hline 17.5 & 1.4827 & -0.0717 & 0.00567 & 0.6312 \\
\hline 100 & 1.499 & -0.0415 & 0.00337 & 0.6421 \\
\hline 175 & 1.4991 & -0.034 & 0.00291 & 0.7344 \\
\hline 289.5 & 1.5121 & -0.0315 & 0.00291 & 0.214 \\
\hline 404 & 1.5377 & -0.0296 & 0.00265 & 0.6643 \\
\hline 611 & 1.5377 & -0.0281 & 0.00254 & 0.7516 \\
\hline 1.5525 & -0.0312 & 0.00281 & 0.6452 \\
\hline
\end{tabular}

Table 5. Regression coefficients of quadratic models $\left(y=A+B x+C x^{2}\right)$ of the effect of moisture content on bulk density at different applied pressures 
Multiple regression of moisture content and applied pressure on bulk density: multiple regression analysis was carried out to assess the effects of water content, applied pressure on bulk density. The range of pressure was 17.5 to $511 \mathrm{kPa}$ and 0 to $13 \%(\mathrm{db})$ water content. The multiple regression equation was:

$$
y=1.4359+0.00017 X_{1}-0.0039 X_{2}, \quad R^{2}=0.6114
$$

where $y=$ bulk density $\left(\mathrm{Mg} / \mathrm{m}^{3}\right), \mathrm{X}_{1}=$ applied pressure $(\mathrm{kPa}), \mathrm{X}_{2}=$ water contents $(\%) \mathrm{db}, \mathrm{R}^{2}=$ coefficient of determination. The multiple regression analysis (Equation 18) showed that the effect of moisture content was greater than that of applied pressure on the bulk density, judging from the higher coefficient of the independent variable, water content.

\subsubsection{Silt loam soil}

i. $\quad$ Physical properties: The soil studied was a silt loam soil according to the USDA textural classification of soils. Table 6 shows some physical and chemical properties of the soil. The consistency limits of the soils are presented in Table 6. Plasticity index is an index of workability of the soil and a large range of plasticity index implies a need for large amounts of energy to work the soil to a desired tilth.

\begin{tabular}{ll}
\hline Property & Values \\
\hline Sand $(\%)$ & 22.6 \\
\hline Silt $(\%)$ & 62.8 \\
\hline Clay $(\%)$ & 14.5 \\
\hline Silt + clay $\%)$ & 77.3 \\
\hline Texture $(\%)$ & Silt loam \\
\hline Organic carbon $(\mathrm{g} / \mathrm{kg})$ & 2.03 \\
\hline Organic matter $(\%)$ & 3.51 \\
\hline Total nitrogen g/kg) & 0.18 \\
\hline pH in $\mathrm{H}_{2} \mathrm{O}(1: 2)$ & 7.93 \\
\hline Ca ${ }^{2+}(\mathrm{cmol} / \mathrm{kg})$ & 0.17 \\
\hline Mg ${ }^{2+}(\mathrm{cmol} / \mathrm{kg})$ & 1.70 \\
\hline Na ${ }^{+}(\mathrm{cmol} / \mathrm{kg})$ & 0.17 \\
\hline $\mathrm{K}+(\mathrm{cmol} / \mathrm{kg})$ & 0.29 \\
\hline $\mathrm{P}(\mathrm{mg} / \mathrm{kg})$ & 4.00 \\
\hline Plastic limit $(\%)$ & 9,2 \\
\hline Liquid limit $(\%)$ & 40 \\
\hline Plasticity index & 30.8 \\
\hline
\end{tabular}

Table 6. Some physical and chemical properties of llorin silt loam soil 
ii. Strength properties: shear strength and cone index are indicators of soil strength. Shear strength is the resistance of soil to shearing or structural failure. The shear strength of an individual clod decreases with wetting, but more importantly, the strength of the bulk soil increases with increasing moisture up to the lower plastic limit at which each particle is surrounded by a film of water which acts as lubricant. Soil strength drops sharply from that point to the upper plastic limit, where the soil becomes viscous. The effects of moisture content and applied pressure on shear strength of the experimental soils are presented in Figure 4. Shear strength increased with increase in applied pressure and moisture content until a peak value was reached after which the value of the parameter declined with further increase in moisture content. This is a typical soil behaviour which has been reported by other researchers. The peak value occurred at higher moisture content as the applied pressure increased. The maximum shear strength of the soils at applied pressure of $600 \mathrm{kPa}$ was $1025 \mathrm{kPa}$ at moisture content of $9.1 \%(\mathrm{db})$. Similarly, the effect of moisture content and applied pressure on cone index of the soil is presented in Figure 5. The relationship is similar to that exhibited by shear strength. The maximum cone index at applied pressure of $600 \mathrm{kPa}$ was $1325 \mathrm{kPa}$ at moisture content of $5.0 \%(\mathrm{db})$. However, the effects of moisture content and applied pressure on bulk density showed different behaviour from those of shear strength and cone index (Figure 6). Bulk density increased with increase in moisture content for all the applied pressure in the range of moisture content considered, however the increase was with a peak at about the plastic limit. Bulk density increased with increase in moisture contents up to a maximum because addition of water increased cohesion. Bulk density decreased at higher moisture content after the peak value because further addition of water created greater water pressure which reduced soil compressibility. The maximum bulk density at applied pressure of $600 \mathrm{kPa}$ was $2.1 \mathrm{Mg} / \mathrm{m}^{3}$ at moisture content of $10.0 \%(\mathrm{db})$. This moisture content was significant because it was the moisture content at which the soil reached maximum bulk density. This is in agreement with other researchers' report that soils with high amount of fine particles (clay plus silt) are more susceptible to compactability [17]. The regression models that describe the behaviour of soil parameters shown in Figures 4 to 6 are presented in Table 7 . The models are largely nonlinear and they agree well with those reported by other researchers $[6,7,8,9,11$, and 12]. Regression models (Table 8) were also established to show relationships between compaction indices such as shear strength, cone index and bulk density at applied pressures of 75, 300 and $600 \mathrm{kPa}$ representing a range of low to medium and high pressures. The relationships varied from linear to exponential and to polynomial functions. The results also found a linear correlation between cone index and shear strength at a low applied pressure of $75 \mathrm{kPa}$. This agrees well with the findings of Vanags et al. [1] who reported linear relationship between cone index and surface shear resistance of soil. 


\begin{tabular}{|c|c|c|c|c|c|}
\hline $\begin{array}{l}\text { Dependent } \\
\text { variables }\end{array}$ & $\begin{array}{l}\text { Independent } \\
\text { variables }\end{array}$ & Predictive models & $\mathbf{R}^{2}$ & $\begin{array}{l}\text { Applied } \\
\text { pressure, } \\
\mathrm{kPa}\end{array}$ & Model type \\
\hline SS & $M C$ & $y=-0.797 x^{2}+21.77 x+21.63$ & 0.9733 & 75 & polynomial \\
\hline SS & $M C$ & $y=-1.384 x^{2}+35.46 x+52.5$ & 0.9394 & 150 & polynomial \\
\hline SS & $M C$ & $y=-2.54 x^{2}+55.09 x+191.1$ & 0.7899 & 300 & polynomial \\
\hline SS & $\mathrm{MC}$ & $y=-3.875 x^{2}+97.17 x+39.08$ & 0.468 & 600 & polynomial \\
\hline$\overline{\mathrm{Cl}}$ & $\mathrm{MC}$ & $y=-1.056 x^{2}+25.1 x+83.75$ & 0.8061 & 75 & polynomial \\
\hline $\mathrm{Cl}$ & MC & $y=-1.53 x^{2}+34.2 x+177.3$ & 0.8384 & 150 & polynomial \\
\hline $\mathrm{Cl}$ & $M C$ & $y=-2.63 x^{2}+52.79 x+342.1$ & 0.7914 & 300 & polynomial \\
\hline $\mathrm{Cl}$ & $M C$ & $y=-4.543 x^{2}+82.54 x+698.9$ & 0.729 & 600 & polynomial \\
\hline $\mathrm{BD}$ & $\mathrm{MC}$ & $y=1.133 e^{0.022 x}$ & 0.9661 & 75 & exponential \\
\hline $\mathrm{BD}$ & $\mathrm{MC}$ & $y=31.4 x+1228.7$ & 0.9624 & 150 & linear \\
\hline $\mathrm{BD}$ & MC & $y=32.02 x+1304.5$ & 0.8976 & 300 & linear \\
\hline $\mathrm{BD}$ & $\mathrm{MC}$ & $y=-0.001 x^{2}+0.059 x+1.395$ & 0.9442 & 600 & Polynomial \\
\hline
\end{tabular}

$\mathrm{Cl}=$ cone index; $\mathrm{BD}=$ bulk density $\mathrm{MC}=$ moisture content; $\mathrm{SS}$ = shear strength

Table 7. Relationships between dependent and independent variables llorin silt loam soil

\begin{tabular}{llllll}
\hline $\begin{array}{l}\text { Dependent } \\
\text { variables }\end{array}$ & $\begin{array}{l}\text { Independent } \\
\text { variables }\end{array}$ & Predictive models & Applied & Model type \\
\hline $\mathrm{Cl}$ & $\mathrm{SS}$ & $y=1.184 x+24.52$ & 0.6651 & 75 & linear \\
\hline $\mathrm{Cl}$ & $\mathrm{SS}$ & $\mathrm{y}=0.0006 \mathrm{x}^{2}+0.97 x+60.5$ & 0.7914 & 150 & polynomial \\
\hline $\mathrm{Cl}$ & $\mathrm{SS}$ & $\mathrm{y}=177.59 \mathrm{e}^{0.0025 x}$ & 0.9687 & 300 & exponential \\
\hline $\mathrm{Cl}$ & $\mathrm{SS}$ & $\mathrm{y}=0.001 \mathrm{x}^{2}-1.406 x+866.8$ & 0.2600 & 600 & polynomial \\
\hline \hline $\mathrm{Cl}$ & $\mathrm{BD}$ & $\mathrm{y}=-627.3 \mathrm{x}^{2}+1890 x-122$ & 0.4711 & 75 & polynomial \\
\hline $\mathrm{Cl}$ & $\mathrm{BD}$ & $\mathrm{y}=-0.0014 \mathrm{x}^{2}+4.42 x-3108.8$ & 0.8094 & 150 & polynomial \\
\hline $\mathrm{Cl}$ & $\mathrm{BD}$ & $\mathrm{y}=-0.0017 \mathrm{x}^{2}+5.30 \mathrm{x}-3108.8$ & 0.4531 & 300 & polynomial \\
\hline $\mathrm{Cl}$ & $\mathrm{BD}$ & $\mathrm{y}=-10128 \mathrm{x}^{2}+36518 \mathrm{x}-31362$ & 0.7790 & 600 & polynomial \\
\hline
\end{tabular}

$\mathrm{Cl}=$ cone index $\mathrm{BD}=$ bulk density $\mathrm{MC}=$ moisture content; $\mathrm{SS}$ = shear strength

Table 8. Relationships between cone index, shear strength and bulk density of Ilorin silt loam soil 


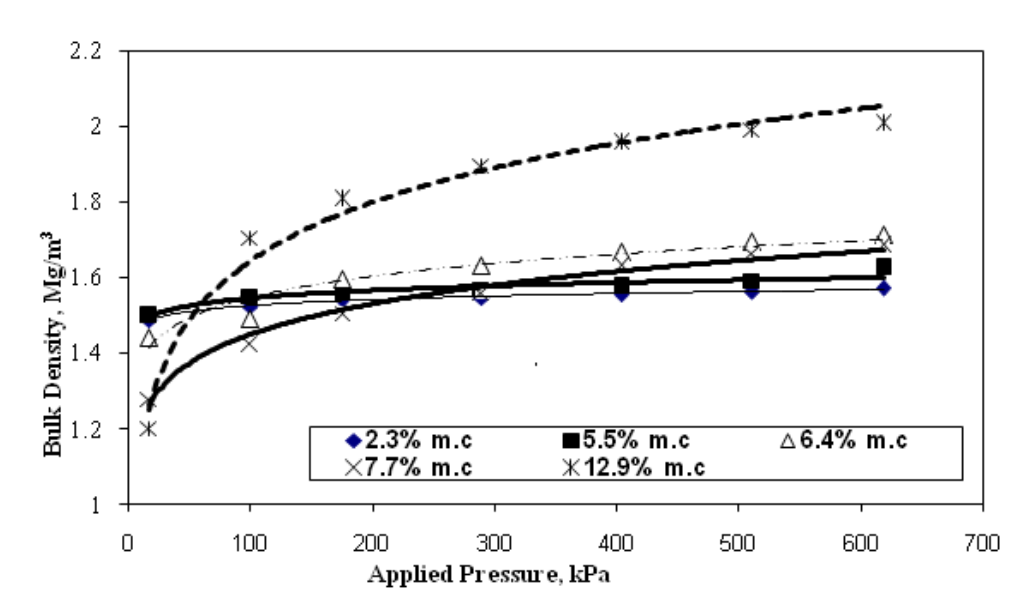

Figure 3. Effect of applied pressure, moisture content on bulk density of sandy clay loam soil (EBS3), Layer3 (52, 17, 31)

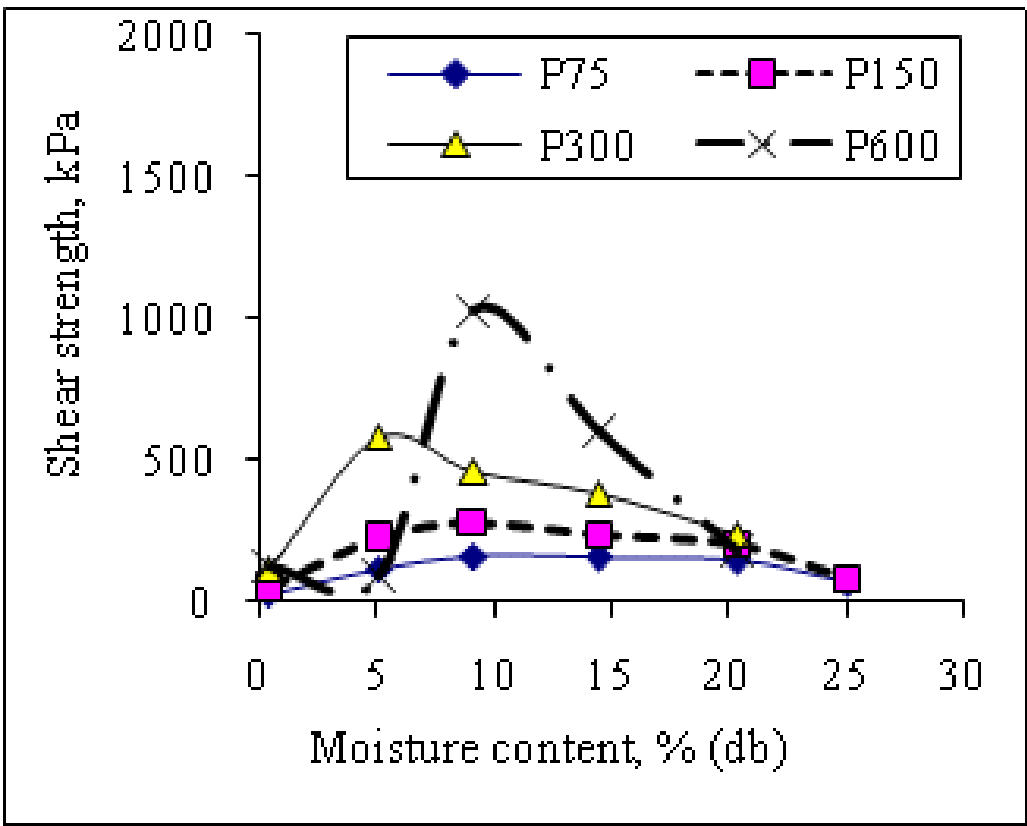

Figure 4. Effect of moisture content and applied pressure on shear strength 


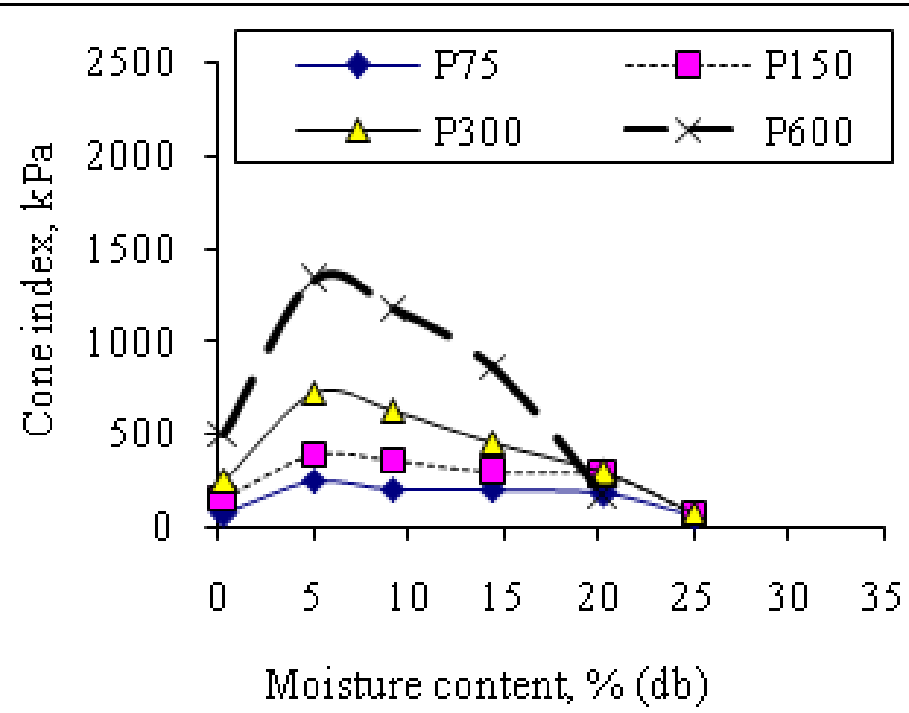

Figure 5. Effect of moisture content and applied pressure on cone index

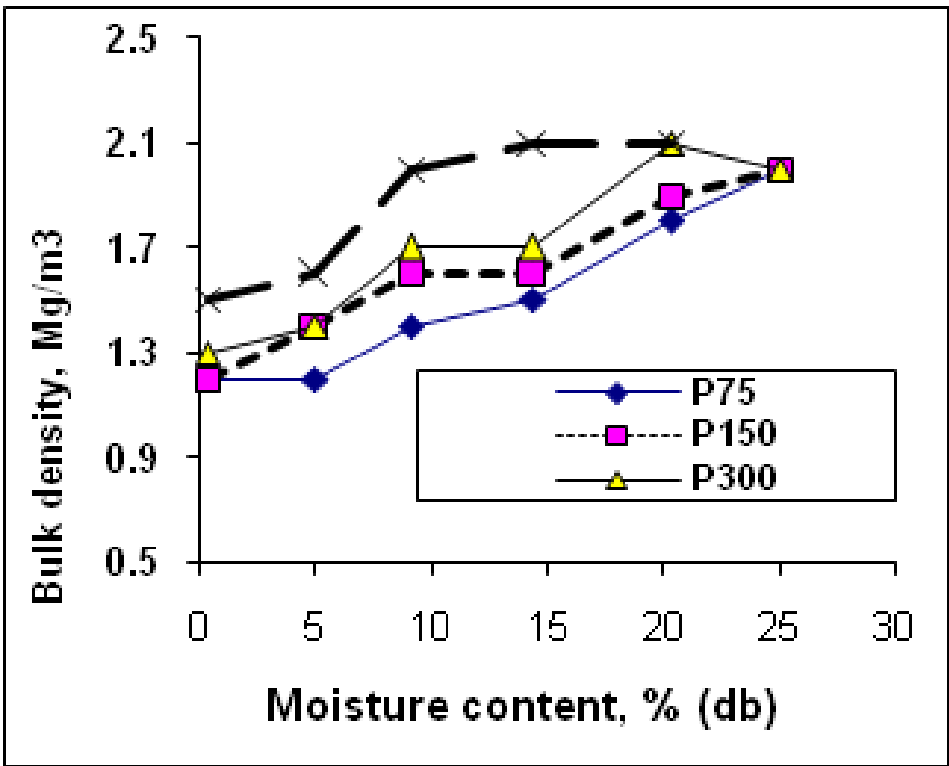

Figure 6. Effect of moisture content and applied pressure on bulk density 


\subsection{Unconfined compression}

\subsubsection{Sandy clay soil}

The most common causes of soil compaction are agricultural machines such as tractors; harvesting equipment and implement wheels travelling over moist, lose soils [24]. Soils tend to be more compacted deeper into the soil profile due to the weight of overlaying soil. Heavily compacted soils contain few large pores, less total pore volume and consequently a greater density [25]. The experimental excavator can be categorized as light machinery in agreement with the report [26]. Also the characteristics of the experimental soil are shown in Table 9. This soil texture (sandy clay) is one of the dominant textures in the locality and even the state in general. Table 10 shows the rut that was produced as a result of the traffic frequency. This was considered to be high for the moisture content range (11 to $15 \%(\mathrm{db}))$ at which the experiment was carried out. A typical excavator track footprint (rut) is shown in Figure 7. For each traffic treatment, cone index, bulk density and rut depth were measured at $2 \mathrm{~m}$ intervals along a $48 \mathrm{~m}$ transect within the excavator tracks (left and right). All measurements were made in the centrelines of the tracks because that was where the compressive effects tend to concentrate [19]. Cone penetration resistance and bulk density were also measured in the control treatment where no tracks (excavator) had passed (Figure 8). Soil penetration resistance at the control site (zero excavator traffic) increased with depth due to shaft friction, and overburden pressure of the weight of soil above the specific depth (Figure 8). Also, lateral forces on the penetrometer cone increase with increasing depth so that more force was needed for the cone to displace soil [27]. Resistance can also increase with depth because of changes in soil texture, gravel content, structure and agricultural traffic if it had occurred. The variation of penetration resistance with depth along the excavator foot prints as a result of machinery traffic is presented in Figure 9. Generally, penetration resistance increased with depth up to a point and then decreased. This trend is consistent with the findings of many researchers. It was observed that the mean values of penetration resistance along the left and right foot prints of the excavator for each treatment were not significantly different from each other at $5 \%$ level of significance. It was reported that bulk density and penetration resistance increase with the number of passes but bulk density tended to be less responsive than penetration resistance [27]. Despite this, the measured changes in bulk density agreed with soil behaviour suggested by changes in penetration resistance. The result of this study agreed with this assertion. Examination of soil responses to traffic in deeper layers revealed that soil compaction increased as the traffic intensity increased. This also agreed with the findings of other researchers [28, 27]. Effect of traffic on bulk density is presented in Table 11 at two depths only due to the limitation imposed by the short (35 $\mathrm{cm}$ ) shank of the penetrometer used in this study. At 9 and 11 passes, soil bulk density became significantly different than at lower traffic frequency. 


\begin{tabular}{ll}
\hline Properties & Values \\
\hline Sand $(\%)$ & 51 \\
\hline Silt $(\%)$ & 10 \\
\hline Clay $(\%)$ & 39 \\
\hline Texture $\%)$ & Sandy clay \\
\hline Organic carbon $(\mathrm{g} / \mathrm{kg})$ & 1.5 \\
\hline Organic matter $(\%)$ & 2.58 \\
\hline $\mathrm{C} / \mathrm{N} \mathrm{ratio}$ & 7.89 \\
\hline Total nitrogen g/kg) & 0.19 \\
\hline $\mathrm{pH}$ in $\mathrm{H}_{2} \mathrm{O}(1: 2)$ & 6.75 \\
\hline $\mathrm{Ca}{ }^{2+}(\mathrm{cmol} / \mathrm{kg})$ & 3.30 \\
\hline $\mathrm{Mg}{ }^{2+}(\mathrm{cmol} / \mathrm{kg})$ & 2.20 \\
\hline $\mathrm{Na}+(\mathrm{cmol} / \mathrm{kg})$ & 0.14 \\
\hline $\mathrm{K}+(\mathrm{cmol} / \mathrm{kg})$ & 0.26 \\
\hline $\mathrm{P}(\mathrm{mg} / \mathrm{kg})$ & 17.54 \\
\hline
\end{tabular}

Table 9. Soil properties of sandy clay soil

\begin{tabular}{cc}
\hline Traffic treatments (No of passes) & Mean rut depth $(\mathbf{m m})$ \\
\hline 1 & $27 \mathrm{a}$ \\
\hline 3 & $45 \mathrm{~b}$ \\
\hline 5 & $70 \mathrm{c}$ \\
\hline 7 & $99 \mathrm{~d}$ \\
\hline 9 & $132 \mathrm{e}$ \\
\hline 11 & $148 \mathrm{f}$ \\
\hline
\end{tabular}

Different letters within each traffic treatments show significant difference at $1 \%$ level of significance, Duncan's multiple range test)

Table 10. Effect of Excavator traffic frequency on rut depth

\begin{tabular}{llllllll}
\hline \multirow{2}{*}{ Depth $(\mathbf{m m})$} & Control plot & \multicolumn{5}{c}{ Excavator traffic frequency (No of passes) } \\
\cline { 3 - 8 } & & 1 & 3 & 5 & 7 & 9 & 11 \\
\hline $0-150$ & 1.242 & $1.251 \mathrm{a}$ & $1.259 \mathrm{a}$ & $1.301 \mathrm{a}$ & $1.319 \mathrm{a}$ & $1.435 \mathrm{~b}$ & $1.442 \mathrm{~b}$ \\
\hline $150-300$ & $1.407 \mathrm{a}$ & $1.422 \mathrm{a}$ & $1.427 \mathrm{a}$ & $1.431 \mathrm{a}$ & $1.439 \mathrm{a}$ & $1.506 \mathrm{~b}$ & $1.534 \mathrm{~b}$ \\
\hline
\end{tabular}

Values with different letters (horizontally Bulk) are significantly different at each depth (P less than 0.001 Duncan's multiple range test).

Table 11. Bulk Density $\left(\mathrm{Mg} \mathrm{m}^{-3}\right)$ at two depths under different degrees of Excavator traffic $(1,3,5,7,9,11)$ 


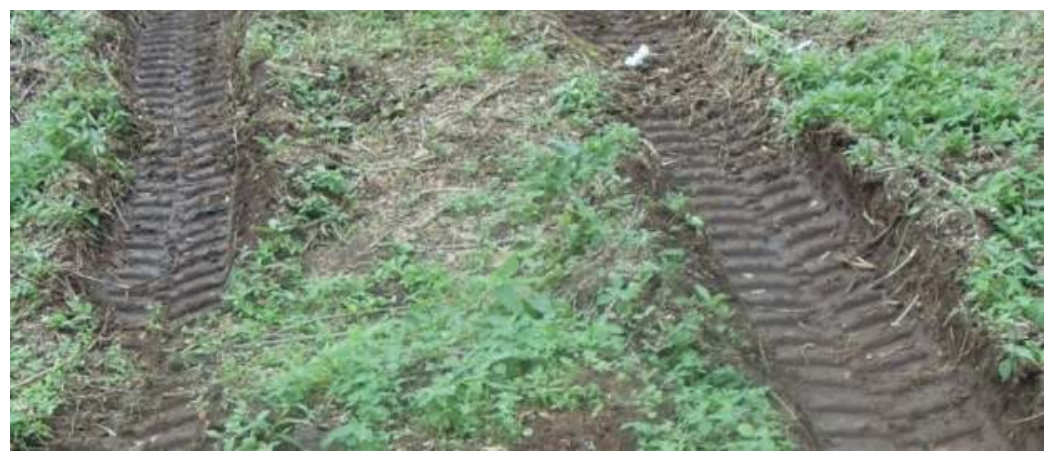

Figure 7. Plan view of the rut produced by the excavator tracks during experimentation

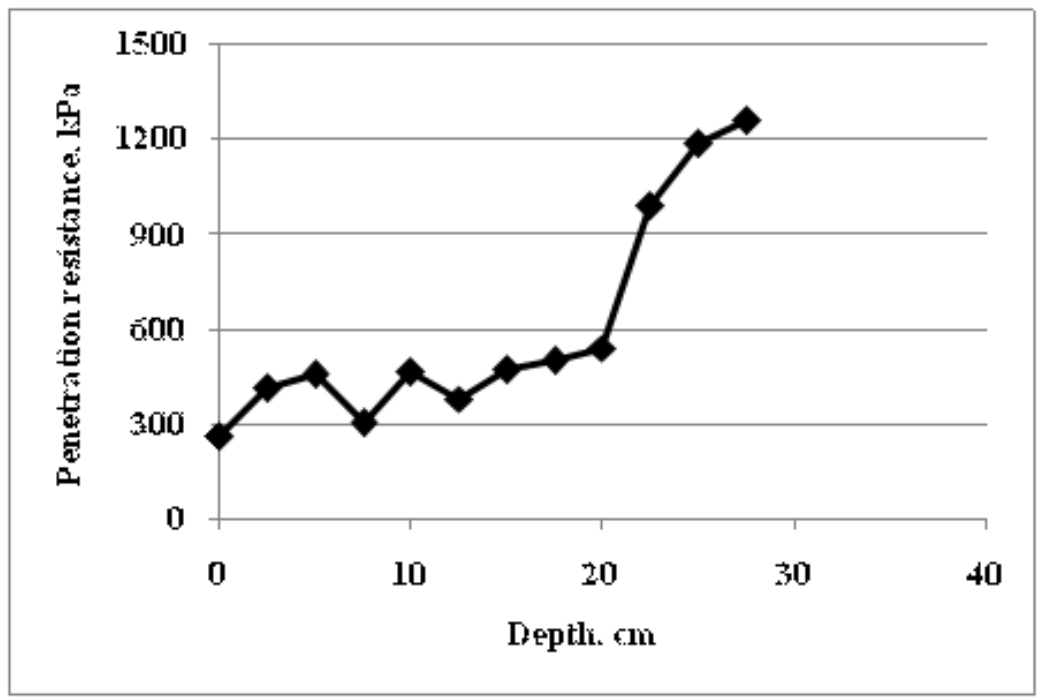

Figure 8. Variation of cone penetration resistance with depth at control plot 


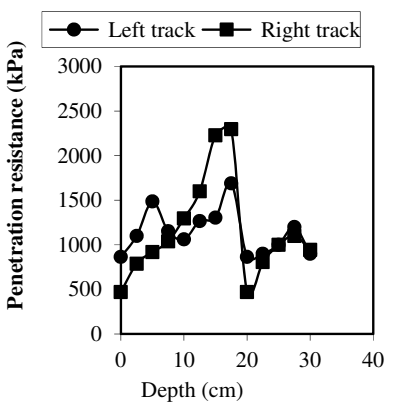

(a)

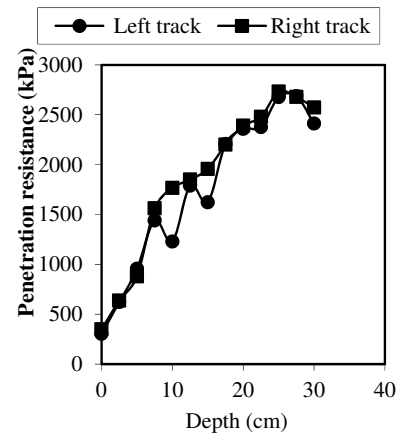

(c)

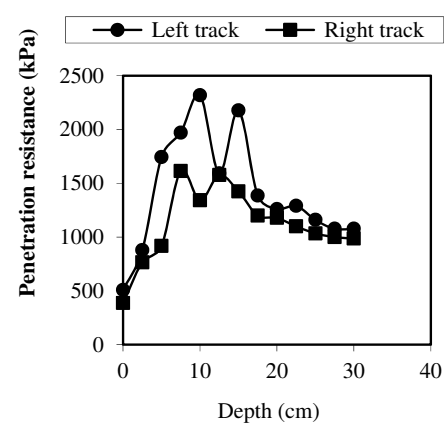

(e)

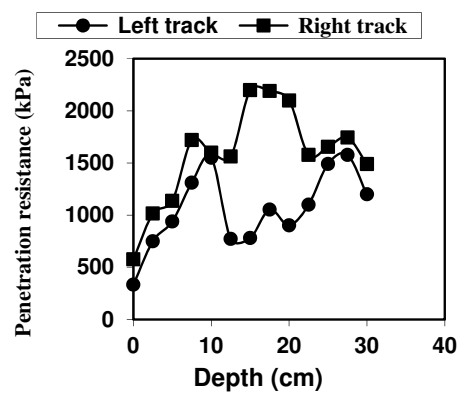

(b)

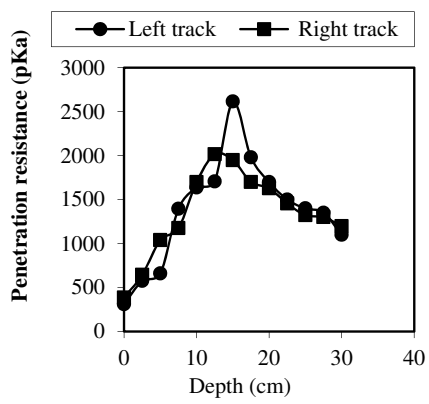

(d)

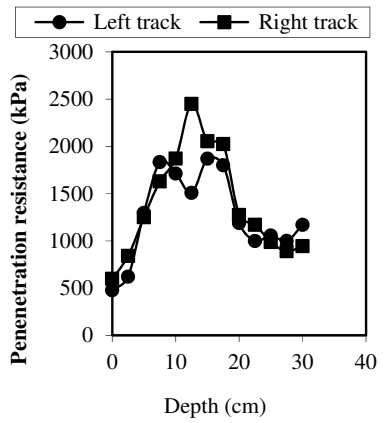

(f)

Figure 9. Cone penetration resistance in the centre lines of the excavator tracks- (a) 1 pass (b) 3 passes (c) 5 passes (d) 7 passes (e) 9 passes (f) 11 passes 


\section{Conclusion}

2. The study shows that compaction behaviour of Akure sandy clay loam soil in a confined compression could be modelled after certain non-linear equations. The model derived from the data can be used to evaluate the relative importance of water content and applied pressure in the compaction process.

3. Similarly, the behaviour of Igbokoda loamy sand soil has been studied.The soil showed similar behaviours in the dry and near saturation conditions. Bulk density varied from 1.2389 to $1.6393 \mathrm{Mg} / \mathrm{m}^{3}$ in the range of applied pressure of 0 to $618 \mathrm{kPa}$. Linear, intrinsically linear and quadratic models can be used to describe the behaviour of the soil for the purpose of predictions. In a multiple regression analysis, it was observed that the principal factor influencing compaction of the loamy sand soil was water content rather than applied pressure at the time of compaction.

4. The study also showed that compaction behaviour of Ilorin silt loam soil could be modelled after certain linear and non-linear regression equations. Cone index have good positive linear relationship with shear strength, but can also be fitted with polynomial (quadratic) function with higher coefficient of determination. The effect of moisture content and applied pressure on cone index, shear strength was best fitted with polynomial function of the second order. The effect of applied pressure and moisture content on bulk density of silt loam could be modelled after linear, exponential and polynomial regression functions. Cone index has good correlation with shear strength

5. The study of the compaction behaviour of Akure sandy clay in unconfined space (field) showed that Cone penetration resistance values under left and right centre lines of excavator tracks was not significantly different from one another. There were significant differences in the mean rut of traffic frequencies at $5 \%$ level of significance. There were also significant differences in the mean bulk density due to traffic frequencies at two depths, at $5 \%$ level of significance.

\section{Acknowledgements}

I hereby acknowledge the following that have made the various studies reported in this chapter possible: the Federal university of Technology, Akure (FUTA), Nigeria for the Senate Research Grant No (URG/MINOR/98/105); the National Centre for Agricultural Mechanisation (NCAM) for the privilege to use the facility of their Research Laboratory; World Bank for the STEP-B research Grant to the Institution (FUTA); and to my numerous undergraduate and post graduate students who have assisted in collecting useful data for the work reported in this chapter. 


\section{Author details}

Seth I. Manuwa*

Address all correspondence to: sethimanuwa@yahoo.com

Department of Agricultural Engineering, School of Engineering and Engineering Technology, The Federal University of Technology, Akure, Nigeria

\section{References}

[1] Vanags, C, Minasny, B, \& Mcbratney, B. and A. B. The Dynamic Penetrometer for Assessment of Soil Mechanical Resistance," (2004). http://www.regional.org.au/au/ asssi/supersoil2004/s14/poster/1565_vanagsc.htm.

[2] Hillel, H. Soil and Water: Physical and processes,". Academic Press, New York, (1971).

[3] Gill, W. R. and G. E. Van den Berg, "Soil Dynamics in Tillage and Traction," Handbook 316, Agricultural Research Service, U. S. Department of Agriculture, Washington, D. C., (1968).

[4] Assouline, S. Modeling Soil Compaction under Uniaxial Compression," Soil Science Society of America Journal, (2002). , 66, 1784-1787.

[5] Koolen, A. J, \& Kuipers, H. Agricultural Soil Mechanics," Springer- Verlag. New York, (1983). , 171-280.

[6] Koolen, A. J. A method of Soil Compatibility Determination,"' Journal of Agricultural Engineering Research, (1974). , 19, 271-278.

[7] Larson, W. E, Gupta, S. C, \& Useche, R. A. Compression of Agricultural Soils from Eight Soil Orders," Soil Science Society of America Journal, (1980). , 44, 450-457.

[8] Saini, G. R, Chow, T. L, \& Ghanen, I. Compatibility Indexes of Some Agricultural Soils of New Brunswick, Canada," Soil Science, (1984). , 137, 33-38.

[9] Gupta, S. C, \& Allmaras, R. R. Models to Assess the Susceptibility of Soil to Compaction," Advances in Soil Science, (1987). , 6, 65-100.

[10] Oni, K. C. Traffic Compaction and Tillage Effects on the Performance of Maize in Sandy loam Soil of Nigeria," Agricultural Mechanization in Asia, Africa and Latin America, (1991). , 22(2), 27-31.

[11] Smith, C. W, Johnston, M, \& Lorentz, A. Assessing the Compaction Susceptibility of South African Forestry Soils. 1. The Effect of Soil Type, Water Content and Applied Pressure on Uni-axial Compaction," Soil Tillage E Research, (1977). , 41, 53-73. 
[12] Fritton, D. D. An Improved Empirical Equation for Uni-axial Soil Compression for a Wide Range of Applied Stresses, Soil Science Society of America, Journal, (2001). , 65, 678-684.

[13] Ohu, J. O, Raghavan, G. S. V, Mckyes, E, \& Mehuys, G. Shear Strength Prediction of Compacted Soils with Varying added Organic Matter Contents," Transactions of the American Society of Agricultural Engineers, (1986). , 29(2), 251-255.

[14] Onwualu, A. P, \& Anazodo, U. G. N. Soil Compaction Effect on Maize Production under Various Tillage Methods in a Derived Savanna Zone of Nigeria, " Soil \& Tillage Research, (1989). , 14, 99-114.

[15] Lambe, T. W. Soil Testing for Engineers,"” John Wiley, New York, (1951).

[16] Walkley, A, \& Black, I. A. An Examination of the Different Methods for Determining Soil Organic Matter and a Proposed Modification of the Chromic Acid Titration Method," Soil Science, (1934). , 37, 29-38.

[17] Krzic, M, Bulmer, C. E, Teste, F, Dampier, L, \& Rahman, S. Soil properties Influencing Comppactability of Forest Soils in British Columbia, Can. J. Sci. (2004). , 84, 219-226.

[18] Manuwa, S. I. (2009). Performance evaluation of tillage tines operating under different depths in a sandy clay loam soil. Soil and tillage research, , 103, 399-405.

[19] Sohne, W. (1958). Fundamentals of pressure distribution and soil compaction under tractor tyres. Agric. Eng. , 39, 276-281.

[20] Dexter, A. R, \& Tanner, D. W. (1973). Response of unsaturated soils to isotropic stress. Journal of Soil Science, , 24, 491-502.

[21] Bertilsson, G. (1971). Topsoil reaction to mechanical pressure. Swede. Journal of Agricultural Research, , 1, 179-189.

[22] Fulton, J. P, Wells, L. G, Shearer, S. A, \& Barnhisel, R. I. (1996). Spatial variation of soil physical properties: A precursor to precision tillage. ASAE Paper International Meeting, Phoenix, Arizona. July (961002), 14-18.

[23] Ssullivan, O, \& , M. F. Uni-axial compaction effects on soil physical properties in relation to soil type and cultivation. Soil \& Tillage Research, , 24, 257-269.

[24] [24]Alakuku, L, Weisskopf, P, Chamen, W. C. T, Tijink, F. G. J, Van Der Linden, J. P, Pires, S, Sommer, C, \& Spoor, G. (2003). Prevention strategies for field traffic-induced subsoil compaction: A review. Part 1.Machine/soil interactions- Soil and Tillage Res., , $73,145-160$.

[25] Horn, R, \& Van Den, J. H. Akker and J. and Arvidsson. (Eds.) ((2001). Subsoil Compaction- Distribution, Processes and Consequences.- Advances in Geology 32, CatenaVerlag, Reiskirchen 
[26] Botta, G. F, Jorajuria, D, Rosatto, H, \& Ferrero, C. (2006). Light tractor traffic frequency on soil compaction in the rolling Pampa region of Argentina, Soil \& Tillage Research, , 86, 9-14.

[27] Becerra, A. T, Botta, G. F, Bravo, X. L, Tourn, M, Melcon, F. B, Vazquez, J, Rivero, D, Linares, P, \& Nardon, G. (2010). Soil compaction distribution under tractor traffic in almond (Prunus amigdalus L. ) orchard in Almeria Espana, Soil \& Tillage Research, , 107(1), 49-56.

[28] Botta, G. F, Jorajuria, D, \& Draghi, L. M. (2002). Influence of the axle load, tyre size and configuration on the compaction of a freshly tilled clayey soil. Journal of Terramechanics, , 39, 47-54. 